\title{
Pengembangan Media Pembelajaran Fisika Menggunakan Software Aurora 3D Materi Pengukuran
}

\author{
Supajrin Nadori ${ }^{1}$, Roro Hoyi ${ }^{2}$ \\ ${ }^{1}$ Sekolah Menengah Atas 8 Kota Jambi, Jambi, Indonesia \\ ${ }^{2}$ Pendidikan Fisika, Universitas Jambi, Jambi, Indonesia
}

\begin{tabular}{l}
\hline \hline Article Info \\
\hline Article history: \\
Received Mar 2, 2020 \\
Revised Apr 28, 2020 \\
Accepted Jul 3, 2020 \\
\hline
\end{tabular}

\section{Keywords:}

Fisika

Modul

Pengukuran

\begin{abstract}
ABSTRAK
Tujuan penelitian: Membuat dan menguji modul pembelajaran fisika pokok bahasan pengukuran.

Metodologi: Jenis penelitian ini adalah penelitian dan pengembangan dengan model pengembangan ADDIE. Uji coba dilakukan melalui validasi ahli media, ahli materi dan uji kelompok kecil. Sample terdiri dari 20 siswa di kelas X SMAN 8 Kota Jambi. Instrumen yang digunakan ialah angket.

Temuan utama: Hasil analisis data menyatakan bahwa persepsi siswa tentang program pembelajaran fisika berbasis Aurora 3D pada materi pokok bahasan pengukuran untuk SMA kelas $X$ untuk persepsi siswa tentang kriteria tampilan program masuk dalam kategori baik $(83,33 \%)$, persepsi siswa tentang kesesuaian program dengan bahan ajar fisika masuk dalam kategori baik $(85,42 \%)$, dan persepsi siswa tentang kualitas teknis temasuk dalam kategori baik $(84,27 \%)$
\end{abstract}

Keterbaruan penelitian: Penguatan penggunaan pengembangan modul untuk materi fisika pokok bahasan Pengukuran.

This is an open access article under the $\underline{C C B Y-N C}$ license

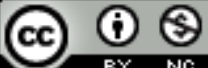

\section{Corresponding Author:}

Supajrin Nadori,

SMAN 8 Kota Jambi, Jambi, Indonesia

Email: nadori.s@gmail.com

\section{PENDAHULUAN}

Sebagai proses komunikasi kegiatan pembelajaran seringkali menemui kendala yang penting disebabkan oleh ketidakmampuan guru dalam menyampaikan materi pelajaran, kemampuan siswa memahami penjelasan guru, dan sumber belajar yang terbatas. Berbagai kendala dalam komunikasi edukatif tentunya juga terjadi pada proses pembelajaran fisika. Meskipun kata fisika berasal dari kata fisik yang berarti wujud atau nyata, tetapi tidak semua materi fisika berwujud fisik yang dapat dilihat, diraba, atau dirasakan. Salah satu contohnya adalah materi tentang pengukuran [1]. Dalam prakteknya akan sangat sulit jika guru memberikan pelajaran fisika dengan selalu mengajak siswa melakukan percobaan, pengukuran, dan analisis. Alasan utamanya adalah sarana dan waktu pembelajaran yang terbatas [2]. Kesulitan inilah yang seringkali membuat sebagian besar guru mengambil jalan pintas dengan memberikan materi yang sudah jadi. [3] menyatakan bahwa, bagi sebagian besar siswa menganggap fisika merupakan mata pelajaran yang dianggap sangat sulit, baik untuk siswa dengan kemampuan tinggi maupun siswa dengan kemampuan rendah.

Kesulitan dalam proses pembelajaran fisika sebenarnya dapat diatasi dengan memanfaatkan teknologi secara optimal. Seperti pemanfaatan komputer dalam bidang pendidikan yang tidak dapat diragukan lagi keberhasilannya, karena komputer merupakan salah media terbaik untuk menyampaikan materi pelajaran. Sampai saat ini sebenarnya telah diproduksi media pembelajaran fisika berbasis komputer 
[4-7]. Media ini berupa soft copy (aplikasi) yang berisi materi pelajaran fisika yang dapat digunakan untuk membantu guru menjelaskan materi pelajaran. Namun demikian, ternyata kebanyakan aplikasi tersebut sulit dicari di pasaran, dan harganya juga relatif mahal. Kondisi ini menyebabkan guru kembali kepada cara mengajar tradisional dengan menjelaskan materi melalui metode ceramah. Sedangkan sebagian guru yang lain mencoba untuk tetap memanfaatkan software PowerPoint sebagai media pembelajarannya. Meskipun penggunaannya relatif mudah, tetapi software PowerPoint relatif memiliki tampilan yang sederhana dan kurang menarik. Selain itu software ini memiliki sistem keamanan yang rendah, sehingga mudah rusak diserang virus komputer. Selain Power Point, program Aurora 3D juga dapat dimanfaatkan sebagai media pembelajaran yang merupakan software pendukung pembuatan efek animasi yang berisi semua efek dalam perangkat lunak Marker 3D, ada berbagai latar belakang yang dinamis, adalah untuk menghasilkan 3D animasi dan banner pilihan terbaik. Aurora 3D memberikan kemungkinan yang lebih besar untuk dapat meningkatkan proses pembelajaran yang lebih efektif dan efisien, sehingga hasil belajar siswa dapat meningkat[8-11].

Hal tersebut diperkuat dengan hasil penelitian yang dilakukan oleh [4] menyebutkan bahwa, media dengan software Aurora 3D memiliki tampilan yang lebih menarik dibandingkan dengan media berbasis Microsoft PowerPoint. Sebesar 78,14\% siswa menyatakan media berbasis Aurora 3D memiliki tampilan sangat baik, sedangkan untuk media Microsoft PowerPoint hanya sebesar 21,86\%. Kemudian hasil penelitian $[12,13]$ menyebutkan bahwa, 69,36\% lebih menyukai software Aurora 3D dibandingkan dengan software PowerPoint dan Macromedia Flash. Selain itu 41,26\% guru menyatakan bahwa software Macromedia Flash memiliki tampilan yang lebih interaktif dibandingkan software Aurora 3D, tetapi memiliki sistem operasi yang lebih rumit dan tingkat kesulitan yang lebih tinggi dibandingkan dengan Aurora 3D.

Adapun tujuan dalam penelitian ini ialah menghasilkan produk media pembelajaran berbasis TIK pada pokok bahasan pengukuran dengan menggunakan software Aurora 3D serta mengetahui persepsi siswa kelas X tentang hasil pengembangan media pembelajaran fisika dengan menggunakan software Aurora 3D.

\section{METODE PENELITIAN}

Jenis penelitian ini adalah penelitian dan pengembangan. Penelitian pengembangan media pembelajaran fisika pada materi pengukuran ini menggunakan model pengembangan ADDIE dengan alur Analyze (analisis), Design (desain), Development (pengembangan), Implementation (Implmentasi), dan Evaluation (evaluasi). Menurut [14] pengembangan media pembelajaran fisika pada materi pengukuran menggunakan program Software Aurora 3D dengan langkah-langkah model penelitian ADDIE sebagai berikut:

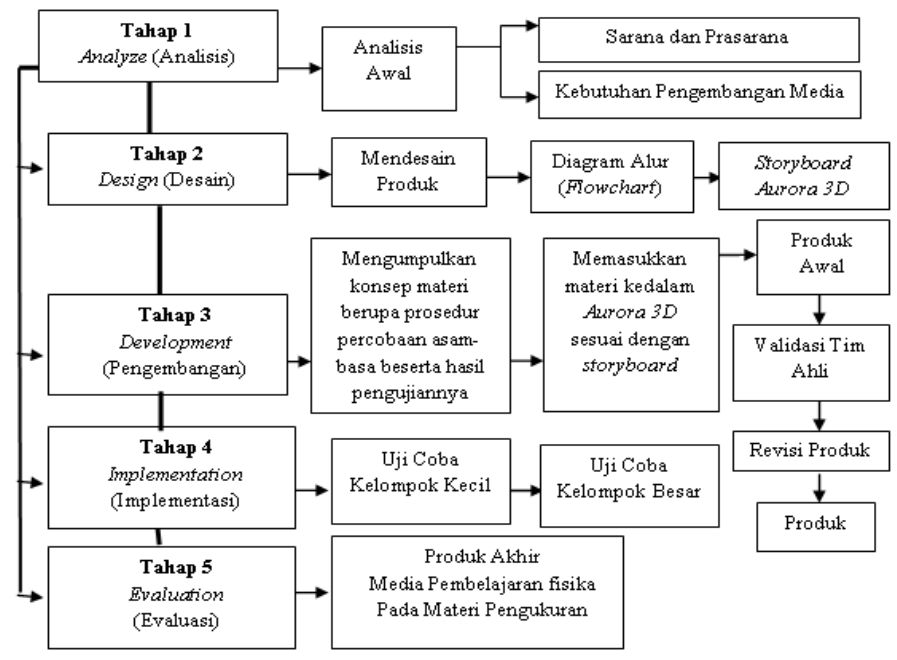

Gambar 1. Langkah-langkah Pengembangan Media Pembelajaran Fisika pada Materi Pengukuran Menggunakan Model Penelitian ADDIE

Subyek uji coba pada penelitian ini adalah siswa kelas X di SMA Negeri 8 Kota Jambi. Uji coba di lakukan melalui kelompok kecil dengan siswa kelas X SMA Negeri 8 Kota Jambi sebanyak 20 orang siswa. Teknik analisa data yang digunakan yaitu kualitatif dan kuantitatif. Data kualitatif menampilkan masukan, anggapan, kritik dan saran ahli dalam perbaikan media maupun ahli materi pembelajaran. Sedangkan data kuantitatif menampilkan persentase dan kategori kelayakan produk melalui persepsi siswa. Selanjutnya data 
persepsi yang telah dikonversi dikelompokkan dalam lima kategori dengan menggunakan kriteria yang didasarkan pendapat [15-17] berikut ini:

Tabel 1. Persentase dan Kategori Persepsi

\begin{tabular}{ccc}
\hline No & Persentase Persepsi & Kategori \\
\hline 1. & $89 \%-100 \%$ & Sangat Baik \\
2. & $61 \%-88 \%$ & Baik \\
3. & $41 \%-60 \%$ & Cukup Baik \\
4. & $12 \%-40 \%$ & Kurang Baik \\
5. & $<12 \%$ & Tidak Baik \\
\hline
\end{tabular}

\section{HASIL DAN PEMBAHASAN}

\subsection{Validasi Ahli Media}

Proses penilaian ini dilakukan sebanyak tiga kali. Berdasarkan saran yang diberikan oleh ahli media pada proses validasi kedua, maka fokus revisi atau perbaikan media diarahkan pada masalah tombol yang kurang terlihat jelas, dan program yang masih berjalan tersendat-sendat. Setelah dilakukan perbaikan media, langkah selanjutnya adalah meminta kembali ahli media untuk memberikan penilaian semua item media telah dinyatakan layak, sehingga media dapat digunakan dalam proses uji coba kepada siswa. Hasil perbaikan warna huruf dapat dilihat pada gambar berikut ini

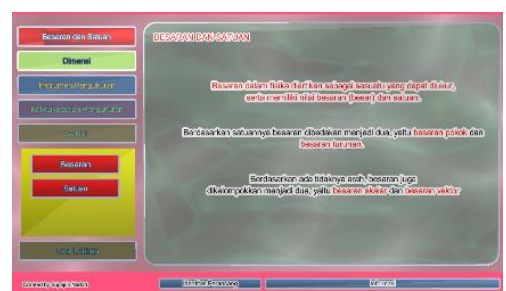

Gambar 2. Sebelum Perbaikan

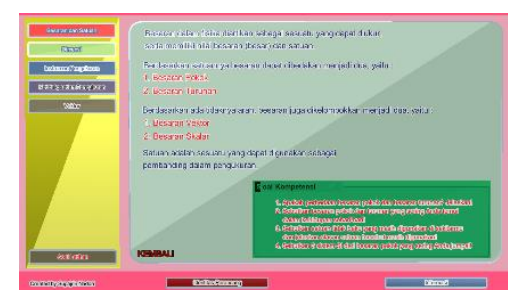

Gambar 3. Setelah Perbaikan

Hasil perbaikan warna tombol atau icon dapat dilihat pada gambar berikut ini

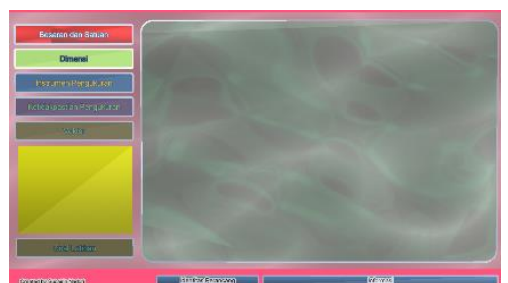

Gambar 4. Sebelum Perbaikan

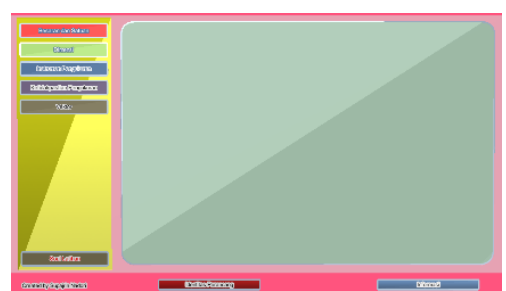

Gambar 5. Setelah Perbaikan

Berdasarkan saran yang diberikan oleh ahli materi pada proses validasi, maka fokus revisi atau perbaikan media diarahkan pada masalah penambahan contoh-contoh soal latihan. Setelah dilakukan perbaikan media, langkah selanjutnya adalah meminta kembali ahli materi untuk memberikan penilaian. Hasil penilaian ketiga ahli materi yaitu semua item media telah dinyatakan layak, sehingga media dapat digunakan dalam proses uji coba kepada siswa.

\subsection{Uji Persepsi siswa}

Tabel 2. Persepsi Siswa pada Penggunaan Media Pembelajaran dengan Software AURORA 3D

\begin{tabular}{clcc}
\hline No & \multicolumn{1}{c}{ Indikator } & Persentase Skor & Kategori \\
\hline 1. & Tampilan Program & $83.33 \%$ & Baik \\
2. & Kesesuaian Media dengan Bahan Ajar & $85.42 \%$ & Baik \\
3. & Siswa Terhadap Penggunaan Media & $85 \%$ & Baik \\
\hline
\end{tabular}

Tabel 2 menunjukkan persepsi siswa pada penggunaan media pembelajaran dengan software AURORA 3D yang ditinjau melalui tiga indikator yaitu tampilan program memiliki persentase rata-rata sebesar 83,33\% dengan kategori baik lalu indikator kesesuaian media dengan bahan ajar memiliki persentase 
sebesar $85,42 \%$ dengan kategori baik dan indikator siswa terhadap penggunaan media memiliki persentase $85 \%$ dengan kategori baik.

Berdasarkan hasil analisis angket dari siswa mengenai program media pembelajaran yang dikembangkan menghasilkan persentase rata-rata sebesar 84,27 \% tergolong dalam katagori baik. Dengan demikian dapat disimpulkan, bahwa dari segi tampilan dan teknis media pembelajaran yang dikembangkan layak untuk dijadikan media pembelajaran fisika pada pokok bahasan pengukuran tentang gerak untuk SMA kelas X. Berdasarkan hasil pengujian yang telah dilakukan, menyatakan bahwa program ini dapat dimanfaatkan dalam pembelajaran fisika pokok bahasan Pengukuran untuk SMA kelas X. Penggunaan program relatif mudah dan sederhana, hanya memasukan input (program) lalu tinggal meng-klik menggunakan mouse sehingga Output akan ditampilkan pada layar. Program ini telah memenuhi syarat kelayakan dengan kriteria yang telah dijelaskan pada bagian hasil diatas [10].

Evaluasi, komentar dan saran-saran dari siswa dan para siswa kemudian dianalisis oleh pengembang media pembelajaran. Setelah dilakukan analisis dari saran dan komentar maka langkah selanjutnya adalah revisi terhadap produk yang telah dikembangkan. Secara umum media yang dikembangkan sudah baik. Dengan adanya inovasi media pembelajaran tentu akan mengatasi keterbatasan ruang, waktu, tenaga, dan daya indra serta menimbulkan gairah belajar, interaksi lebih langsung antara siswa dengan sumber belajar [18-19].

\section{KESIMPULAN}

Berdasarkan hasil analisis dan pembahasan diatas bahwa persepsi siswa tentang program pembelajaran fisika berbasis Aurora 3D pada materi pokok bahasan pengukuran untuk SMA kelas X untuk persepsi siswa tentang kriteria tampilan program masuk dalam kategori baik $(83,33 \%)$, persepsi siswa tentang kesesuaian program dengan bahan ajar fisika masuk dalam kategori baik $(85,42 \%)$, dan persepsi siswa tentang kualitas teknis temasuk dalam kategori baik $(84,27 \%)$. Dengan demikian program yang dikembangkan layak dijadikan sebagai media pembelajaran dan dapat dimanfaatkan dalam pembelajaran Fisika pokok bahasan Pengukuran untuk siswa SMA kelas X.

\section{UCAPAN TERIMA KASIH}

Peneliti mengucapkan terimakasih kepada validator ahli media dan ahli materi, Kepala Sekolah SMAN 8 Kota Jambi, guru dan siswa atas partisipasinya dalam membantu keberhasilan penelitian ini.

\section{REFERENSI}

[1] R.S. Budiarti, A. Sadikin, "Pengaruh Kwartet Animalia Dengan Model TGT Terhadap Pemahaman Materi Taksonomi Hewan Siswa SMAN 8 Kota Jambi,” Jurnal Biodik,vol. 1, no. 1, pp. 1-9, 2015.

[2] Abdurrahman, Gardjito, R. S. Budiarti, "Pengembangan Lembar Kegiaan Siswa Berbasis Penemuan Terbimbing Pada Materi Struktur Dan Fungsi Jaringan,” Jurnal Biodik, vol.1, no. 1, pp. 1-8, 2015.

[3] A. L. Putri, Maison, Darmaji, "Kerjasama Dan Kekompakan Siswa Dalam Pembelajaran Fisika Di Kelas XII MIPA SMAN 3 Kota Jambi,” Edu Fisika: Jurnal Pendidikan Fisika, vol.3 no.2, pp. 32-40, 2018.

[4] A. Fujika, E. Anggreini, R.S. Budiarti, "Analisis Kemampuan Berfikir Kritis Siswa SMAN 5 Kota Jambi Melalui Pembelajaran Berbasis Masalah Pada Konsep Pencemaran Lingkungan,” Jurnal Biodik, vol. 1 no. 1, pp. 1-10, 2015.

[5] M. Naswir, Haryanto, and Ferawati, "Analisis Keterlaksanaan Model Pembelajaran Inkuiri Tertimbang Untuk Materi Sifat Koligatif Larutan dan Pengaruhna Terhadap Kemampuan Beroikir Kreatif Siswa Kelas XII IPA SMA Islam Al-Falah Kota Jambi,” J. Indo. Soc Integ.Chem, vol. 9, no. 2, pp.43-51, 2016.

[6] E. Sari, Syamsurizal, and Asrial, "Pengembangan Lembaga Kegiatan Peserta Didik (LKPD) Berbasis Karakter Pada Mata Pelajaran Kimia SMA,” Edu-Sains, vol. 5, no. 2, pp. 8-17, 2016.

[7] Dewi, R.S. Budiarti, and M. Aina, "Pengembangan Lembar Kegitaan Peserta Didik (LKPD) Bermuatan Pendidikan Karakter Dengan Model Pembelajaran Guided Inqury Pada Materi Bakteri Bagi Siswa Kelas X Sekolah Menengah Atas," Jurnal Biodik, vol. 3, no.1, pp. 17-26, 2017.

[8] P. M. Purbosari, "Pembelajaran Berbasis Proyek Membuat Ensiklopedia Ilmu Pengetahuan Alam (IPA) Untuk Meningkatkan Academic Skill Pada Mahasiswa," Scholaria, vol. 6, no. 3, pp. 231-238, 2016.

[9] Nurdyansyah, and L. Riananda, "Developing ICT-Based Learning Model to Improve Learning Outcome IPA of SD Fish Market in Sidoarjo," Proceeding of International Research Clinic and Scientific Publications of Educational Technology, 2016.

[10] B.B. Akpan, "Innovation In Science And Technology Education Through Science Teacher Associations," International Council of Associations For Science Education, vol. 21, no. 2, pp. 67-69, 2010. 
[11] S.Pransiska, R. Asyhar, and Asrial, "Pengaruh Penerapan Model Pembelajaran Group Investigation Dan Motivasi Terhadap Hasil Belajar Siswa Kelas VII Di SMP Dalam Pembelajaran IPA Terpadu Pada Materi Asam, Basa Dan Garam,”Edu-Sains, vol. 5, no. 2, pp. 27-31, 2016.

[12] R. D. Yediarni, Maison, and A. Syarkowi, "Scientific Reasoning Abilities Profil Of Junior High School Students In Jambi," International Journal of Science And Education, vol. 3, no. 1, pp. 21-25, 2019.

[13] R. Galuh, "Hubungan Keterampilan Berpikir Kritis dan Literasi Sains pada Pembelajaran IPA Terpadu dengan Model PBM dan STM,” JPPI, vol. 2, no.2, pp. 131-146, 2016.

[14] Maison, Syahrial, Syamsurizal, and Tanti, "Learning, Environment, Students' Beliefs, And Self-Regulation In Learning Physics: Structural Equation Modelling," Journal of Baltic Science Education, vol. 18, no. 3, pp. 389-403, 2019

[15] Asrial., Syahrial., D. A. Kurniawan, F. Chan, R. Septianingsih, and R. Perdana, "Multimedia innovation 4.0 in education: E-Modul Ethnoconstructivism,” Universal Journal of Educational Research, vol. 7, no. 10, pp. 2098 2107, 2019.

[16] Asrial, Syahrial, D.A. Kurniawan, R. Perdana, P. Nugroho, "Supporting Technology 4.0: Ethoconstructivist Multimedia for Elementary Schools,” iJOE, vol. 15, no. 14, pp. 54-66, 2019.

[17] S. Syahrial, A. Asrial, D. A. Kurniawan, F. Chan, A. Hariandi, R. A. Pratama, P. Nugroho, R. Septiasari, "The Impact of Etnocontructivism in Social Affairs on Pedagogic Competencies," Journal of Evaluation and Research in Education (IJERE), vol. 8, no. 3, pp. 409-416, 2019.

[18] M. D. W. Ernawati, Haryanto, and S. CP. Nababan, "Analisis Penerapan Model Pembelajaran Kooperatif Numbered Head Together (NHT) dan Pengaruhnya Terhadap Hasil Belajar Siswa Pada Materi Struktur Atom di Kelas X SMKN 3 Kota Jambi,” J. Ind. Soc. Integ. Chem, vol. 9, no.1, pp.45-53, 2017.

[19] A. Asrial, S. Syahrial, D. A. Kurniawan, M. Subandiyo, and N. Amalina, "Exploring Obstacles In Language Learning Among Prospective Primary School Teacher," International Journal of Evaluation And Research In Education (IJERE), vol. 8, no.2, pp. 249-254, 2019. 